\title{
Monocytic Cell Type-specific Transcriptional Induction of Collagenase
}

\author{
R.A. Pierce, S. Sandefur, G.A.R. Doyle, and H.G. Welgus \\ Division of Dermatology, Department of Internal Medicine, Washington University School of Medicine at Jewish Hospital, \\ St. Louis, Missouri 63110
}

\begin{abstract}
Interstitial collagenase (MMP-1), a metalloproteinase produced by resident and inflammatory cells during connective tissue turnover, cleaves type I collagen fibrils. This catalytic event is rate limiting in remodeling of tissues rich in fibrillar collagen such as the skin and lungs. The regulation of collagenase expression is cell-type specific; bacterial LPS and zymosan, a yeast cell wall derivative, are potent inducers of collagenase expression in macrophages, but do not alter fibroblast collagenase expression. Since promoter elements controlling collagenase transcription in monocytic cells have not been previously defined, we sought to delineate responsive cis-acting elements of the collagenase promoter in transiently transfected human (U937) and murine (J774) monocytic cell lines. Deletion constructs containing as little as 72 bp of $5^{\prime}$-flanking sequence of the collagenase promoter were sufficient for LPS- or zymosan-mediated transcriptional induction, whereas phorbol inducibility exhibited an absolute requirement for upstream elements including the polyoma enhancer A-binding protein-3 site $(-83$ to -91$)$ and TTCA sequence $(-102$ to -105$)$ in both monocytic cells and fibroblasts. Mutagenesis of the activator protein-1 [AP-1] site at -72 abolished basal promoter activity and LPS/zymosan inducibility, while mutagenesis of an NFlike site at -20 to $-\mathbf{1 0}$ had no effect. Nuclear extracts from LPS- and zymosan-treated cells showed strong AP-1 activity by gel-shift analysis, and supershift analysis showed the AP-1 complexes contained specific members of both the jun and fos gene families. These data indicate that, in contrast to most LPS effects, AP-1, but not nuclear factor- $-\mathrm{B}$, mediates LPS induction of collagenase transcription in macrophagelike cells. Furthermore, as compared to regulation by phorbol ester, collagenase induction in monocytic cells by cell wall derivatives of bacteria or yeast is largely independent of upstream promoter sequences. (J. Clin. Invest. 1996. 97:1890-1899.) Key words: collagenase - transcription • monocytic • LPS • AP-1
\end{abstract}

Address correspondence to Dr. Richard A. Pierce, Division of Dermatology, Jewish Hospital, 216 South Kingshighway, St. Louis, MO 63110. Phone: 314-454-8284; FAX: 314-454-8293; E-mail: rpierce@ imgate.wustl.edu

Received for publication 9 November 1995 and accepted in revised form 16 January 1996.

J. Clin. Invest.

(C) The American Society for Clinical Investigation, Inc.

0021-9738/96/04/1890/10 \$2.00

Volume 97, Number 8, April 1996, 1890-1899

\section{Introduction}

In vertebrate tissues, abundant fibrillar collagens, which are resistant to most proteinases, provide a durable architecture. Only three vertebrate proteinases efficiently degrade fibrillar collagens; thus, this step is often rate limiting in tissue remodeling. These collagenases, which are interstitial collagenase (MMP-1) (1, 2), neutrophil collagenase (MMP-8) (3), and collagenase-3 (MMP-13) $(4,5)$, are members of the matrix metalloproteinase (MMP) family of enzymes. Collectively, MMPs can degrade virtually all components of the extracellular matrix (6). In humans, MMP-1 is the predominant collagenase of resident cells such as fibroblasts and keratinocytes, and also of tissue macrophages. MMP-13 expression in humans is apparently much more restricted, being observed in breast carcinomas (5) and articular cartilage (Welgus, H., unpublished observations), but not in tissue macrophages. However, in rodents MMP-13 is the only collagenase thus far identified; MMP-1 apparently does not exist as a functional gene in rodents. In humans, neutrophil collagenase is largely restricted to PMNs and is the sole collagenolytic enzyme of those cells.

Interestingly, the regulation of interstitial collagenase (MMP-1) is cell-type specific. Resident cells (e.g., fibroblasts, keratinocytes, endothelial cells) can produce interstitial collagenase and other metalloproteinases in response to growth factors such as EGF (7) and basic fibroblast growth factor (8), and in response to inflammatory cytokines such as TNF- $\alpha$ (9) and IL-1 (10), but macrophages are not responsive to these factors. In contrast, mediators such as LPS (11) and zymosan (12) induce collagenase production in cells of the monocytic lineage, but have no effect on production of collagenase or other metalloproteinases by resident cells of epithelial or mesenchymal origin. The induction of collagenase expression in monocytic cells is likely transcriptionally mediated, as the monocytic cell line U937, when differentiated with phorbol ester, increases collagenase transcription when exposed to LPS (13).

The molecular mechanisms controlling metalloproteinase expression in resident cells such as fibroblasts and keratinocytes have been exclusively studied. The promoters of the interstitial collagenase and stromelysin- 1 genes are similar in overall structure (14), and these genes are often coordinately regulated. Transcriptional induction of the collagenase and stromelysin promoters in fibroblasts is dependent not only on the prototypical activator protein-1 $(\mathrm{AP}-1)^{1}$ sites found near the transcription start sites of these promoters, but also upon upstream sequences including a polyoma enhancer A-binding protein-3 (PEA-3) site and TTCA element $(10,14,15)$. Thus, in resident cells of mesenchymal or epithelial origin, upstream sequences are critical for inducibility of collagenase expression.

1. Abbreviations used in this paper: AP-1, activator protein-1; NF-кB, nuclear factor-кB; PEA-3, polyona enhancer A-binding protein-3. 
In contrast to such resident cells, the gene regulation of metalloproteinase expression in mononuclear phagocytes has not been studied, at least in part because of the difficulty in transfecting these populations. Yet collagenase expression by macrophages is prominent in inflammatory and matrixdestructive diseases including rheumatoid arthritis $(16,17)$, atherosclerosis $(18,19)$, and idiopathic pneumonia syndrome (Welgus, H. G., unpublished observations). Bacterial LPS activation of macrophages causes a marked induction of interstitial collagenase expression (11), as well as the induction of proinflammatory cytokines such as IL-1 (20), TNF- $\alpha$ (21), and IL-6 (22). Similarly, phagocytosis of zymosan, a yeast cell wall derivative, results in activation of diverse macrophage functions, including the production of interstitial collagenase (12). Induction of many inflammatory genes in macrophages such as TNF- $\alpha$ (23-25), IL-1 (26), and tissue factor (27) by LPS is mediated, in large part, by nuclear factor (NF)- $\mathrm{B}$, a pleiotropic transcriptional transactivator (28). Interestingly, the collagenase promoter contains a sequence at -20 to -10 which is similar to consensus NF-кB-binding sequences.

In this manuscript, we have delineated promoter sequences necessary for monocytic transcriptional induction of collagenase in response to the cell type-specific stimulating agents LPS and zymosan by employing a transient transfection strategy with promoter chloramphenicol transferase (CAT) constructs derived from the collagenase gene. Interestingly, we found that maximal fold induction of collagenase promoter activity by LPS or zymosan was conferred by constructs containing as little as $72 \mathrm{bp}$ of $5^{\prime}$-flanking sequence. Mutation of the AP-1 site abolished both basal activity and induction of promoter activity. In contrast, mutation of the NF-кB-like site did not affect either basal activity or induction of transcription. Binding of specific members of the jun and fos gene family to the collagenase AP-1 site was strongly induced by LPS treatment, implicating AP-1 in transactivation. Thus, in cells of monocytic origin, in contrast to resident cells such as fibroblasts, induction of collagenase transcription is mediated almost entirely through proximal promoter elements involving mainly the AP-1 site.

\section{Methods}

U937 Cell culture, transfections, and CAT assay. Human U937 cells (CLR 1593; American Type Culture Collection, Rockville, MD) were cultured in serum-containing RPMI 1640 medium as described previously (13). Cells were cultured at $5 \times 10^{5} \mathrm{cells} / \mathrm{ml}$ for all treatments and at $1.8 \times 10^{5} / \mathrm{cm}^{2}$ on tissue culture plastic (Costar Corp., Cambridge, MA). To differentiate U937 cells for adherence and to prime for LPS stimulations, PMA (Sigma Chemical Co., St. Louis, MO) in DMSO was added at $50 \mathrm{ng} / \mathrm{ml}$ to the medium alone or simultaneously with LPS (Sigma Chemical Co.). Control cultures received vehicle alone.

For each promoter-CAT construct, $1 \times 10^{7} \mathrm{U} 937$ cells in $1.5 \mathrm{ml}$ of medium were transiently transfected in suspension by exposure to 75 $\mu \mathrm{g}$ DEAE-Dextran (Profection kit; Promega Corp., Madison, WI) and $10 \mu \mathrm{g}$ of supercoiled column-purified DNA (QIAGEN, Inc., Chatsworth, CA) at room temperature for $20 \mathrm{~min}$. After pelleting by gentle centrifugation, cells were resuspended in $60 \mathrm{ml}$ of medium and divided into three $100-\mathrm{cm}^{2}$ dishes to recover overnight. Next, the cultures were washed and treated with control medium, medium containing PMA at $50 \mathrm{ng} / \mathrm{ml}$, or medium containing PMA at $50 \mathrm{ng} / \mathrm{ml}$ plus LPS at $10 \mu \mathrm{g} / \mathrm{ml}$. U937 cells were harvested after $24 \mathrm{~h}$ with a cell scraper. Equivalent amounts of lysates, normalized for total protein
(Bradford protein assay; Bio-Rad Laboratories, Palo Alto, CA), were assayed for CAT activity as described above.

J774 Cell culture, transfections, and CAT assay. Murine J774 cells (TIB 67; American Type Culture Collection) were cultured in DMEM supplemented with $10 \%$ heat-denatured FBS, nonessential amino acids, L-glutamine, and penicillin-streptomycin. These spontaneously adherent, macrophagelike cells were cultured in 6-well cluster dishes containing $5 \times 10^{5}$ cells/well. Liposome-mediated cotransfection of these cells used LipofectAMINE (GIBCO BRL, Gaithersburg, MD) at $10 \mathrm{mg} / \mathrm{ml}$ and $2 \mu \mathrm{g}$ of supercoiled promoterCAT construct with $1 \mu \mathrm{g}$ of plasmid cytomegalovirus (pCMV)- $\beta$-galactosidase as a control for transfection efficiency. After transfection, cells were treated with control medium or medium containing LPS at $10 \mu \mathrm{g} / \mathrm{ml}$ or zymosan at $1 \mathrm{mg} / \mathrm{ml}$. After $24 \mathrm{~h}$, cells were harvested for preparation of lysates as described previously (29). Lysates were assayed for $\beta$-galactosidase activity as described (30) and subsequently for CAT activity using acetyl CoA (Sigma Chemical Co.) and $\left[{ }^{14} \mathrm{C}\right]$ chloramphenicol (DuPont-NEN, Boston, MA), followed by TLC and autoradiography.

Human skin fibroblast culture. Primary cultures of human skin fibroblasts were obtained by explanting from newborn foreskins. Cultures were maintained in supplemented DMEM identical to the culture medium used for J774 cells. Passage 3-8 cells were plated in P-100 dishes at $1.5 \times 10^{6}$ cells per dish and cotransfected by calcium phosphate precipitation as described (31) with $20 \mu \mathrm{g}$ of each collagenaseCAT construct and $5 \mu \mathrm{g}$ of pCMV- $\beta$-galactosidase as a control for transfection efficiency. After $6 \mathrm{~h}$, cells were shocked with $15 \%$ glycerol for $2 \mathrm{~min}$, then treated with either control medium, medium containing PMA at $50 \mathrm{ng} / \mathrm{ml}$, or medium containing LPS at $10 \mu \mathrm{g} / \mathrm{ml}$ for $24 \mathrm{~h}$ before harvest by scraping. Lysates were prepared, assayed for $\beta$-galactosidase activity, and subsequently for CAT activity as described above.

RNA isolation and hybridization. Northern analyses were done to determine the degree of induction of collagenase gene expression with various treatments. Total RNA was isolated from $10^{7}$ treated or control cells as described (32). Northern hybridizations were done as described previously (29). DNA probes were radiolabeled by random priming with $\left[\alpha-{ }^{32} \mathrm{P}\right] \mathrm{dCTP}$. Human procollagenase mRNA from U937 cells was hybridized with a full-length human procollagenase cDNA; mouse collagenase mRNA from J774 cells was detected with pUMR C'ase, a 2.2-kb rat collagenase cDNA clone (4). For glyceraldehyde3-phosphate dehydrogenase (GAPDH) mRNA, pRGAPDH13, a 1.3-kb rat cDNA, was used as described (33). After stringent washing, membranes were exposed to AR x-ray film (Eastman Kodak Co., Rochester, NY) at $-70^{\circ} \mathrm{C}$ for 4 to $24 \mathrm{~h}$ with an intensifying screen.

Construction of reporter constructs. The construct pCLCAT, containing sequences from -2278 to +36 of the human collagenase promoter, was a generous gift from Dr. Stephen Frisch (La Jolla Cancer Research Foundation, La Jolla, CA). The PstI site was mutated to an XhoI site, then the HindIII/XhoI fragment containing the human collagenase promoter sequences of pCLCAT was subcloned into HindIII/XhoI digested pBLCAT2 (34), giving rise to pCL-2278CAT. A series of deletion constructs were synthesized by PCR amplification of linearized pCL-2278CAT, in each case using a unique $5^{\prime}$ primer with an engineered HindIII site and a common $3^{\prime}$ primer within the CAT gene. The resultant PCR products were digested with HindIII and XhoI and subcloned into the HindIII/XhoI digested pBLCAT2 backbone. The $5^{\prime}$ primers used in the PCR amplification, named for the most $5^{\prime}$ nucleotide with identity to collagenase promoter sequences, were as follows:

-511: 5'CAGGAAGCTTAACAAAGGCAGAAAGG3',

-179: 5'TTTGAAGCTTATCATGACATTGCAA3',

-95: 5'TTCAAAGCTTATCAAGAGGATGTTA3',

-72: 5'TATAAAGCTTGAGTCAGACACCTCT3',

-55: 5'CCTCAAGCTTTCTGGAAGGGCAAGGA3',

-34: 5'GGGCAAGCTTTCTATATATACAGAG3'.

The sequence of the $3^{\prime}$ primer, complementary to sequences within the bacterial chloramphenicol (CAT) gene contained in pCL- 
2278CAT, was 5'TTCATTGCATACGGAATTCCGGATG3' . A mutant construct, pCL-2278CATmAP-1, with the AP-1 site replaced by an SmaI restriction site, was constructed by overlapping PCR mutagenesis as described (35). The sequences of the overlapping primers were as follows: (forward primer): 5'GCACCCGGGAGACACCT CTGGCTTTCT3', (reverse primer): 5'TCTCCCGGGTGCTTTAT AAC ATATCCTCT3'. The external primers were: (forward primer): 5'AAGCCATGGTCGTATCGC3', (reverse primer) 5'CCAATTCC CTCGAGCCCGTAAGTGATG3'.

The resultant mutated PCR product was digested with KpnI and XhoI. The digested fragment was then ligated with the HindIII/KpnI fragment of the pCL-2278CAT vector and HindIII/Xhol digested pBLCAT2. Constructs $-511 \mathrm{mAP}-1,-179 \mathrm{mAP}-1$, and $-95 \mathrm{mAP}-1$ were synthesized by PCR amplification of pCL-2278CATmAP-1 using the specific forward primers described above and the common reverse primer complementary to sequences within the CAT gene, followed by restriction digestion with HindIII and XhoI and subcloning into HindIII/XhoI digested pBLCAT2. Constructs $-179 \mathrm{mNF \kappa B}$ and $-95 \mathrm{mNF \kappa B}$ were constructed by overlapping PCR mutagenesis using pCL-2278CAT as a template. The sequences of the overlapping PCR primers were as follows: (forward primer): 5'GAGAACTACCA AGCTGGGATATTGGAGC3', (reverse primer): 5'TTGGTAGTTCACTCTGTATATATAGAGT3'. The sequences of all constructs were verified by dideoxy sequencing of plasmid DNA (Sequenase; Amersham Corp., Arlington Heights, IL).

Preparation of nuclear extracts. Nuclear extracts were prepared from U937 cells treated with control medium containing PMA (50 ng/ $\mathrm{ml})$ or PMA + LPS $(10 \mu \mathrm{g} / \mathrm{ml})$ as described (36). Nuclear extracts were also isolated from $2 \times 10^{8} \mathrm{~J} 774$ cells treated with control medium or medium containing LPS at $10 \mu \mathrm{g} / \mathrm{ml}$ or zymosan at $1 \mathrm{mg} / \mathrm{ml}$ for $24 \mathrm{~h}$. Nuclear extracts were aliquoted and frozen over liquid $\mathrm{N}_{2}$ until use.

Electrophoretic mobility shift assays. To determine the binding of nuclear factors to regions of the collagenase promoter, doublestranded oligonucleotides were synthesized, end labeled with $\left[{ }^{32} \mathrm{P}\right]-\gamma$ ATP (ICN, Biomedicals, Inc., Irvine, CA) and polynucleotide kinase (Boehringer Mannheim Biochemicals, Indianapolis, IN), incubated with $5 \mathrm{mg}$ of nuclear extract protein, and electrophoresed through $5 \%$ nondenaturing polyacrylamide gels essentially as described (37). Extracts were incubated with $1 \mu \mathrm{g}$ poly (dI:dC/dI:dC) and 5- to 50fold excess of specific or mutant unlabeled competitors for $15 \mathrm{~min}$ at $25^{\circ} \mathrm{C}$, then 40,000 to $100,000 \mathrm{cpm}$ of probe was added and incubated for $30 \mathrm{~min}$ at $25^{\circ} \mathrm{C}$. For supershift assays, the reaction mixture was chilled on ice, $1 \mu \mathrm{g}$ of antibody was added, and the incubation was continued overnight at $4^{\circ} \mathrm{C}$. Antibodies were rabbit polyclonals (Santa Cruz Biotechnology, Santa Cruz, CA) raised against specific fos or jun peptide sequences as follows: the pan-jun-specific antibody (c-jun/AP-1 [D]) recognizes the $\mathrm{COOH}$ terminus of mouse c-Jun p39; the c-Jun antibody (c-jun/AP-1 [N]) recognizes amino acids 95-105 of mouse c-Jun p39; the Jun B antibody (jun B [N-17]) recognizes amino acids 45-61 of mouse Jun B p39; the pan-Fos-specific antibody (c-fos[K-25]) was raised against amino acids $128-152$ of human c-fos p62; the c-fos-specific antibody (c-fos [4]) was raised to amino acids 3-16 of human c-Fos p62; and the Fos B-specific antibody was raised to amino acids $102-117$ of the mouse fos $B$ gene product. Binding reactions were centrifuged at $4,000 \mathrm{~g}$ for $5 \mathrm{~min}$ at $4^{\circ} \mathrm{C}$, then electrophoresed through $5 \%$ acrylamide gels at $250 \mathrm{~V}$ for $2 \mathrm{~h}$ at $4^{\circ} \mathrm{C}$. Gels were dried and exposed to $\mathrm{x}$-ray film for $12-30 \mathrm{~h}$.

\section{Results}

LPS treatment upregulates collagenase $m R N A$ expression in monocytic cell lines. To demonstrate the induction of interstitial collagenases in monocytic cells by LPS treatment, Northern blot analysis was performed on total RNA isolated from PMA-differentiated, LPS-treated, human U937 cells. Interstitial collagenase mRNA was undetectable in control cells, in-
A

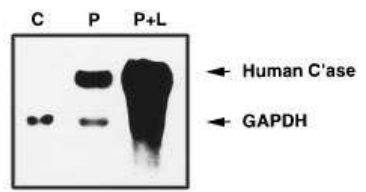

B

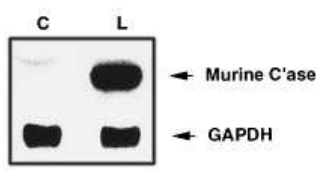

Figure 1. Northern analysis of collagenase mRNA in U937 and $\mathbf{J} 774$ cells. $(A)$ Human U937 cells were treated with control medium $(C), 50 \mathrm{ng} / \mathrm{ml}$ of PMA $(P)$, or with $50 \mathrm{ng} / \mathrm{ml}$ of PMA plus $10 \mu \mathrm{g} / \mathrm{ml}$ of LPS $(\mathrm{P}+\mathrm{L})$ for $24 \mathrm{~h}$, then harvested for RNA isolation and Northern blot analysis of collagenase mRNA levels. Collagenase mRNA is induced by PMA and further induced by LPS treatment. (B) Murine $\mathrm{J} 774$ cells were treated with control medium $(C)$ or with $10 \mu \mathrm{g} / \mathrm{ml}$ of LPS $(L)$ for $24 \mathrm{~h}$, then harvested for RNA isolation and Northern blot analysis of collagenase mRNA levels. Collagenase mRNA is induced by LPS.

duced by PMA differentiation, and markedly potentiated by LPS treatment, as described previously (Fig. $1 A$ ) (13). In spontaneously adherent mouse J774 cells, collagenase mRNA was undetectable in control cultures, but was markedly induced in LPS-treated cultures (Fig. $1 B$ ). These results were uniformly seen in multiple experiments.

LPS-responsive elements of the human collagenase MMP-1 promoter differ from PMA-responsive elements and reside near the transcription start site. Previous studies indicate that LPS stimulation of collagenase expression in monocytic cells was transcriptionally mediated (13). To delineate LPS-responsive elements in the collagenase (human MMP-1) promoter, a series of collagenase promoter-CAT constructs (Fig. $2 A$ ) were used in transient transfections of PMA-differentiated human U937 cells. As shown in Fig. $2 \mathrm{~B}$, induction of promoter activity of LPS treatment was evident in all constructs containing the AP-1 site, including pCL-72CAT. Furthermore, as quantified in Table I, the fold induction by LPS was very similar in pCL-72CAT to all other constructs containing additional upstream sequences. In contrast, the fold induction of transcription with PMA treatment diminished markedly with deletion of the sequences between -179 and -95 (lacking TTCA) and no PMA-mediated induction was observed with pCL-72CAT (Lacking TTCA and PEA-3, but containing AP-1). These data indicate that in monocytes, as reported in fibroblasts $(14,15)$, PMA induction of collagenase transcription is dependent upon

Table I. Induction of Collagenase Promoter Activity by PMA and LPS

\begin{tabular}{cccc}
\hline $\begin{array}{c}\text { Promoter } \\
\text { construct }\end{array}$ & $\begin{array}{c}\text { U937 cells, } \\
\text { LPS/PMA }\end{array}$ & $\begin{array}{c}\text { U937 cells, } \\
\text { PMA/control }\end{array}$ & $\begin{array}{c}\text { J774 cells, } \\
\text { LPS/control }\end{array}$ \\
\hline-2278 & 4.7 & 6.4 & 4.1 \\
-551 & 3.9 & 4.8 & 4.6 \\
-179 & 4.3 & 3.3 & 4.8 \\
-95 & 2.8 & 1.3 & 8.5 \\
-72 & 3.8 & 0.7 & 4.8 \\
-55 & 1.0 & 0.8 & 1.4 \\
-34 & 1.3 & 0.8 & 1.1 \\
\hline
\end{tabular}

Data are derived from scintillation counting of the thin layer chromatographs which were exposed for autoradiography and shown in Fig. 2, $B$ and $C$. Control values are set to 1.0 and numbers presented indicate fold stimulation relative to control. In the case of LPS/PMA for U937 cells, PMA values are set to 1.0 and numbers presented indicated LPS stimulation relative to PMA. 
A

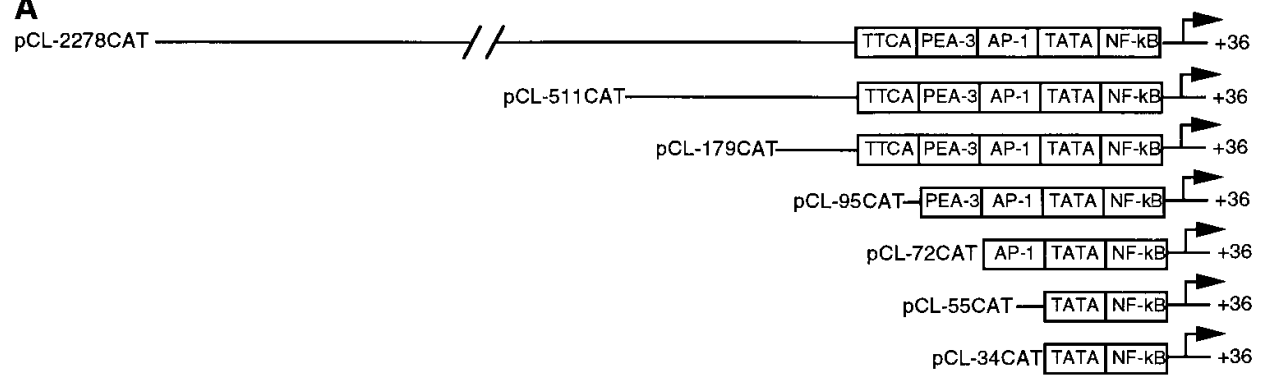

B

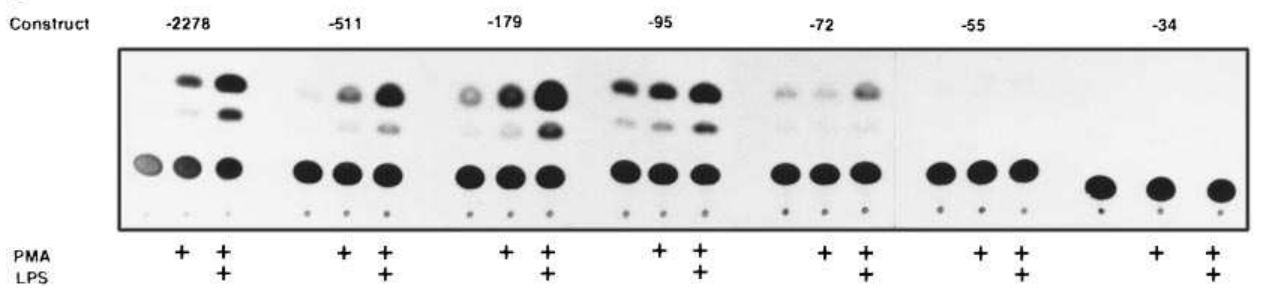

C

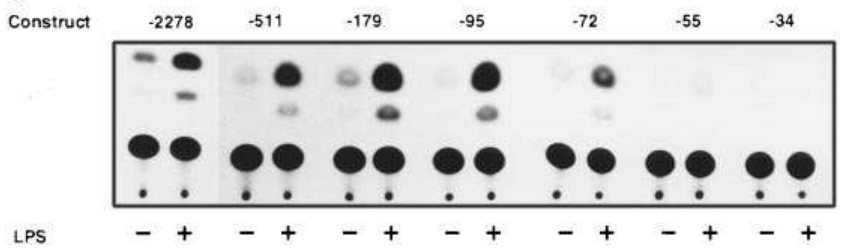

D

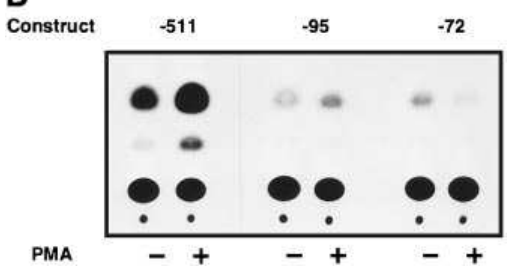

\section{E}

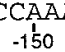
PEA-3 $-140$ AP-1 AP-1 1 GAGACAC $\begin{array}{ccc}-90 & -80 & -70 \\ -90 & -10\end{array}$ TATA $-30$ $\begin{array}{lllllll}-2278 & -179 & -95 & -72 & -55 & (\text { TRE })_{3} \text { TK }\end{array}$

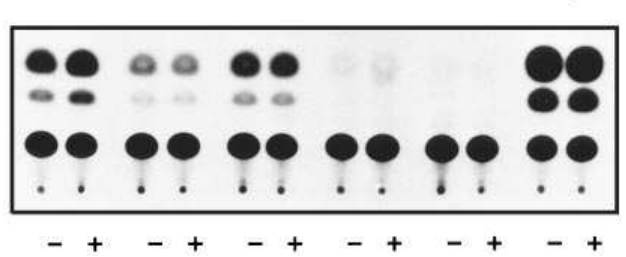

Figure 2. Deletion analysis indicates LPS-responsive elements reside near the collagenase transcription start site. ( $A$ ) A deletion series, containing from 2278 to 34 nucleotides of $5^{\prime}$-flanking sequence of the human collagenase (MMP-1) promoter and extending to +36 relative to the transcription start site, was constructed. (B) U937 cells were transiently transfected with collagenase promoter-CAT constructs, divided into treatment groups, then treated for $24 \mathrm{~h}$ with control medium, $50 \mathrm{ng} / \mathrm{ml}$ of PMA or $50 \mathrm{ng} / \mathrm{ml}$ of PMA plus 10 $\mu \mathrm{g} / \mathrm{ml}$ LPS. Cells were then harvested and lysates prepared for analysis of CAT activity. Constructs containing from 2278 to 179 nucleotides of 5 '-flanking sequence were induced by PMA, while induction by LPS occurred with the -95 and -72 constructs as well. $(C) \mathrm{J} 774$ cells were transiently cotransfected with collagenase promoter-CAT constructs and CMV- $\beta$ Gal, treated for $24 \mathrm{~h}$ with $10 \mu \mathrm{g} / \mathrm{ml}$ LPS, then harvested for analysis of CAT activity normalized for $\beta$-galactosidase activity. Note that LPSmediated induction of transcriptional activity was evident in constructs containing from 2278 to 72 nucleotides of $5^{\prime}$-flanking sequence. $(D)$ Human dermal fibroblasts were transiently cotransfected with collagenase promoter-CAT constructs and CMV- $\beta$ Gal, treated for $24 \mathrm{~h}$ with $\mathrm{ng} / \mathrm{ml}$ PMA, then harvested for analysis of CAT activity normalized for $\beta$-galactosidase activity. Transcriptional induction was evident in the -511 construct, but absent in both the -95 and -72 constructs. (E) Human dermal fibroblasts were transiently

cotransfected with either collagenase promoter-CAT-deletion constructs or a heterologous construct containing three tandem AP-1 sites and the HSV TK promoter, and CMV- $\beta$ Gal, treated for $24 \mathrm{~h}$ with LPS at $10 \mu \mathrm{g} / \mathrm{ml}$, then harvested for analysis for CAT activity normalized for $\beta$-galactosidase activity. No induction was observed.

upstream sequences, such as TTCA and PEA-3. However, LPS-induced collagenase transcription exhibited no such dependence. Similarly, in J774 cells treated with control medium or LPS at $10 \mu \mathrm{g} / \mathrm{ml}$ for $24 \mathrm{~h}$ (Fig. 2 C), LPS induction persisted in all constructs containing the AP-1 site. In fact, fold induction of the -72 construct in response to LPS was nearly identical in magnitude to that exhibited by the $-511,-179$, and -95 constructs (Table I). Both basal promoter activity and LPS induction were absent in the -55 and -34 constructs that do not contain the AP-1 sequence.

To compare induction of collagenase transcription in monocytic cells with interstitial cells, human dermal fibroblasts were transfected with collagenase promoter deletion constructs and treated with either PMA or LPS for $24 \mathrm{~h}$. In these cells, as previously reported (38), sequences $5^{\prime}$ of the AP-1 site were required for PMA responsiveness; in fact, a -95 construct containing AP-1 and PEA-3 elements, but lacking TTCA, exhibited no phorbol induction (Fig. $2 \mathrm{D}$ ). As anticipated, human dermal fibroblasts were not competent to upregulate collagenase promoter activity in response to LPS (Fig. $2 E$ ). In all experiments using constructs containing from 2278 to $34 \mathrm{bp}$ of $5^{\prime}$-flanking sequence of the collagenase promoter, LPS induction was never evident. These data indicate that LPS induction of collagenase transcription is cell type specific and 
A

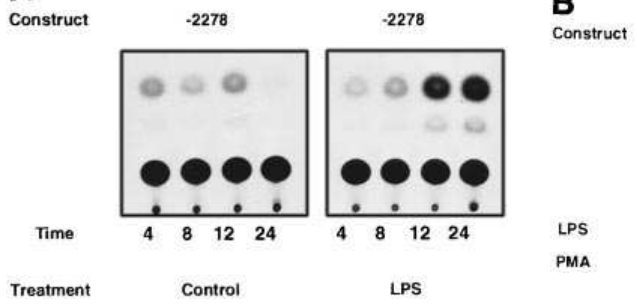

B

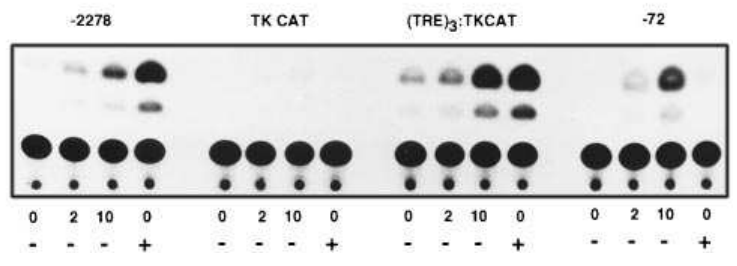

Figure 3. Time course and dose response of LPS induction of collagenase transcription. (A) J774 cells were transfected with -2278CLCAT, treated with LPS at $10 \mu \mathrm{g} / \mathrm{ml}$ for $4,8,12$, or $24 \mathrm{~h}$, then cell lysates were assayed for CAT activity. Induction of transcription was evident by $12 \mathrm{~h}$, and continued at $24 \mathrm{~h}$. (B) Dose response of LPS induction. J774 cells were transiently transfected with collagenase promoter-CAT constructs or heterologous promoter-CAT constructs, treated with PMA at $50 \mathrm{ng} / \mathrm{ml}$ or LPS at 2 or $10 \mu \mathrm{g} / \mathrm{ml}$ for $24 \mathrm{~h}$. Cell lysates were assayed for CAT activity. PMA-mediated transcriptional induction was evident in -2278CLCAT and a heterologous construct containing three tandem repeats of the collagenase AP-1 site, but not in the minimal thymidine-kinase promoter or the native collagenase - 72CLCAT construct. In contrast, LPSmediated transcriptional induction was complete and dose dependent in the native collagenase -72CLCAT construct.

differs from PMA induction of collagenase in requirements for sequences upstream of the AP-1 site.

Time course of LPS induction of collagenase promoter activity. We were interested in determining the time course of induction of collagenase promoter activity by LPS treatment of monocytic cells and chose to perform these studies in the murine $\mathrm{J} 774$ cells, which respond directly to LPS without requiring PMA differentiation. J774 cells were transiently transfected, then treated with LPS for 4, 8, 12, or $24 \mathrm{~h}$. Collagenase promoter activity was slightly induced by LPS treatment at $8 \mathrm{~h}$ over control levels, was fully induced by $12 \mathrm{~h}$, and continued at high levels through $24 \mathrm{~h}$ (Fig. $3 \mathrm{~A}$ ). In some experiments, the

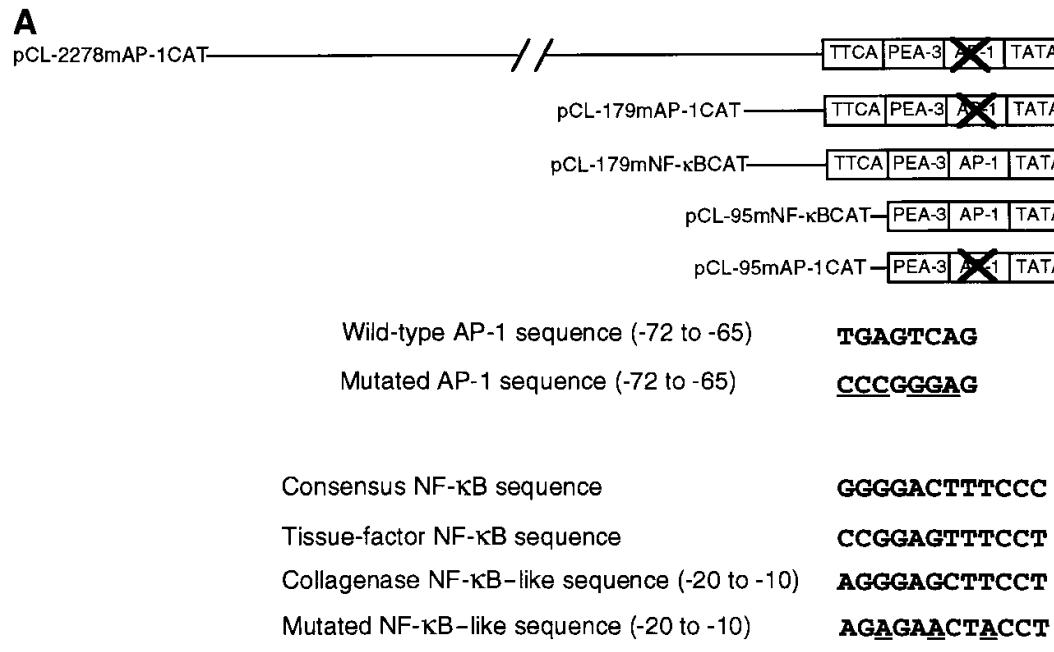

B

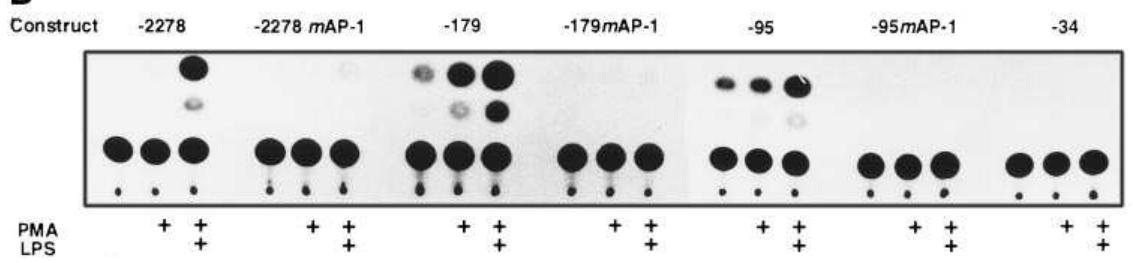

C

Construct

$\begin{array}{llllll}-2278 & -2278 \mathrm{mAP}-1 & -179 & -179 \mathrm{mAP}-1 & -95 & -95 \mathrm{mAP}-1\end{array}$

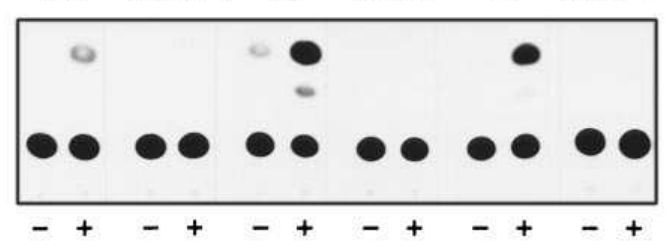

$-179 \quad-179 \mathrm{mNF}-\mathrm{XB}$

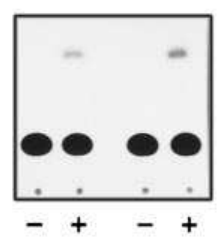

Figure 4. The AP-1 site is necessary for LPS-mediated transcriptional induction. (A) The collagenase AP-1 site and a putative NF-кB-like site were mutated in the context of deletion constructs. (B) U937 cells were transiently transfected, treated with PMA at 50 $\mathrm{ng} / \mathrm{ml}$ or PMA at $50 \mathrm{ng} / \mathrm{ml}$ plus LPS at $10 \mu \mathrm{g} / \mathrm{ml}$ for $24 \mathrm{~h}$, then harvested and cell lysates were assayed for CAT activity. LPS inducibility was evident in constructs containing 2278,179 , or 95 nucleotides of promoter sequences, but mutation of the AP-1 site eliminated both basal activity and inducibility. $(C)$ J774 cells were transiently transfected, treated with LPS at $10 \mu \mathrm{g} / \mathrm{ml}$ for $24 \mathrm{~h}$, then harvested and cell lysates were assayed for CAT activity. Two separate experiments, one testing $\mathrm{mAP}-1$ constructs and another, the mNF-кB construct, are presented. Note that mutation of the AP-1 site in the context of the $-2278,-179$, and -95 constructs abolished basal activity and LPS inducibility. In contrast, mutation of the NF$\kappa \mathrm{B}-$ like site had no effect on LPS inducibility. 
increase at $8 \mathrm{~h}$ was quite evident; however, a high level of induction was always observed at $12 \mathrm{~h}$.

LPS induction of collagenase promoter activity is dose responsive. To determine if the LPS-mediated induction of collagenase transcription was dose dependent, transiently transfected J774 cells were treated with 2 to $10 \mu \mathrm{g} / \mathrm{ml}$ of LPS or with PMA at $50 \mathrm{ng} / \mathrm{ml}$ for $24 \mathrm{~h}$ (Fig. $3 \mathrm{~B}$ ). Constructs containing 2278 or just 72 bp of $5^{\prime}$-flanking sequence were equally LPS responsive and a dose-dependent increase in transcriptional activity was observed. While transcriptional activity from the -2278 construct was highly responsive to PMA, the -72 construct was completely unresponsive to PMA treatment, similar to Fig. 2 B. A control plasmid containing the herpes simplex virus thymidine kinase promoter linked to the CAT gene (34) exhibited no transcriptional activity, while a derived construct that contains three tandem repeats of the Ap-1 site inserted 5' of the thymidine kinase promoter exhibited basal activity, PMA responsiveness, and dose-dependent induction with LPS treatment of J774 cells. These data further support the hypothesis that the single collagenase AP-1 site linked to minimal downstream sequences is necessary and sufficient for LPSmediated induction of collagenase transcription, but not for PMA-induced transcription.

The AP-1 site, but not the NF- $\kappa B$-like site, is necessary for LPS-mediated transcriptional induction. To determine whether an intact AP-1 site was necessary for collagenase transcription in the context of larger collagenase promoter fragments, sitedirected mutagenesis of the collagenase promoter AP-1 site was performed (Fig. 4 A). In U937 cells, mutation of the AP-1 site ablated transcriptional activation by LPS in the context of the $-2278,-179$, and -95 collagenase promoter-CAT constructs (Fig. 4 B). Similarly, the constructs -2278mAP-1, $-179 \mathrm{mAP}-1$, and $-95 \mathrm{mAP}-1$ all lacked basal activity and LPS inducibility in transfected $\mathrm{J} 774$ cells (Fig. 4 C).

The human collagenase promoter contains a site similar to consensus sequences for the transcription factor NF-кB between the TATA box and the transcription start site (Figs. $2 A$ and $4 A$ ). Because NF-кB is a common transactivator of LPSresponsive genes associated with inflammation (28), we mutated the collagenase NF-кB-like site to test whether this site is important in the LPS-mediated induction of collagenase transcription (Fig. 4 C). Mutation of this NF-кB-like site had no effect on LPS inducibility of the transcriptional activity of

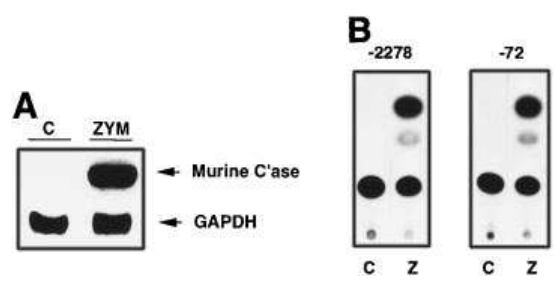

Figure 5. Zymosan induction of collagenase transcription. (A) J774 cells were treated with control medium $(C)$ or zymosan $(Z Y M)$ at 1 $\mathrm{mg} / \mathrm{ml}$ for $24 \mathrm{~h}$, then harvested for RNA isolation and Northern analysis of murine collagenase mRNA. Note that zymosan treatment induced collagenase mRNA. (B) J774 cells were transfected with CL2278CAT or CL-72 CAT, treated with zymosan at $1 \mathrm{mg} / \mathrm{ml}$ for $24 \mathrm{~h}$, and then cell lysates were assayed for CAT activity. Transcriptional activity was potently induced by zymosan treatment and equivalently in the -2278 , and -72 constructs. the -179 promoter-CAT construct in $\mathrm{J} 774$ cells. In this experiment, which was performed separately from the experiment testing the AP-1 mutants, a lower level of CAT activity was due to a lower level of transfection efficiency. However, LPS inducibility over the zero background was evident with or without mutation of the NF-кB-like site. Together, these data argue that the AP-1 site, but not the NF-кB-like site, is necessary for LPS-mediated induction of collagenase transcription in monocytic cells.

Zymosan induction of collagenase in J774 cells. Our experiments indicated that LPS induction of collagenase transcription was mediated primarily through the AP-1 site and was much less dependent on upstream sequences than the induction of collagenase in fibroblasts or monocytic cells by PMA. We were therefore interested in determining whether similar regulatory mechanisms would be characteristic of zymosan induction of collagenase, as this is another agent that, like LPS, activates human macrophage collagenase expression, but has no effect on collagenase expression in other cells such as fibroblasts (12). The spontaneously adherent $\mathbf{J} 774$ cells respond to zymosan by upregulation of collagenase mRNA (Fig. $5 A$ ); however, the PMA-differentiated U937 cells did not respond to zymosan treatment (data not shown). Therefore, we tested the response of the collagenase promoter to zymosan in J774 cells. Transiently transfected, zymosan-treated J774 cells exhibited marked and near-equivalent induction of collagenase promoter activity with deletion constructs containing 2278 and $72 \mathrm{bp}$ of $5^{\prime}$-flanking sequence of the collagenase promoter (Fig. 5 B). Similar results were obtained with deletion constructs containing from 511 to $95 \mathrm{bp}$ of $5^{\prime}$-flanking sequence (data not shown).

LPS and zymosan treatment results in induction of $A P-1$ and $N F-\kappa B$. Because our transient transfection analysis of the collagenase promoter implicated the AP-1 element in both LPS- and zymosan-mediated induction, we were interested in analyzing the induction of AP-1 complexes in U937 and J774 cells. Nuclear extracts were prepared from U937 cells treated for $24 \mathrm{~h}$ with PMA or PMA plus LPS and from J774 cells treated for $24 \mathrm{~h}$ with LPS or zymosan as described above. The quality of all extracts was assessed by mobility-shift assays using the constitutive nuclear protein Oct 1 (data not shown). Extracts were incubated with ${ }^{32} \mathrm{P}$-radiolabeled doublestranded oligonucleotides containing the collagenase promoter wild-type AP-1 site (Fig. $6 A$ ). Extracts from untreated U937 cells exhibited little binding to the AP-1 oligonucleotide, while extracts prepared from LPS-treated, PMA-differentiated U937 cells exhibited greater binding to the AP-1 site than extracts derived from cells treated with PMA alone (Fig. $6 \mathrm{~B}$ ). Competition with fivefold excess unlabeled AP-1 oligonucleotide diminished binding and a 50-fold excess abolished binding, while mutant competitor had no effect on binding activity. Thus, specific binding to the collagenase AP-1 site is potentiated by LPS treatment of PMA-differentiated U937 cells. Similarly, extracts from control J774 cells exhibited some binding to the AP-1 site, which was markedly increased in extracts from LPS treated cells (Fig. $6 C$ ). This binding was competed by a fivefold molar excess of unlabeled competitor, indicating a high degree of specificity of binding. Further increases in unlabeled competitor abolished specific binding completely, while a mutated competitor was ineffective in competing for binding even at a 50-fold excess concentration. In nuclear extracts from zymosan-treated J774 cells, a marked, specific in- 


\section{A}

Collagenase AP-1 probe

Collagenase mAP-1 probe

Consensus NF-KB probe

Collagenase NF-KB-like probe

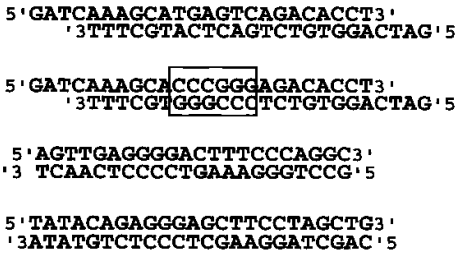

C

\begin{tabular}{|c|c|c|c|c|c|c|c|c|c|c|c|}
\hline Extract & - & \multicolumn{5}{|c|}{ Control } & \multicolumn{5}{c|}{ LPS } \\
\hline Competitor & - & & $5 \mathrm{X}$ & $10 \mathrm{x}$ & $50 \mathrm{x}$ & & & $5 \mathrm{X}$ & $10 \mathrm{x}$ & $50 \mathrm{X}$ & \\
\hline Mutcompetitor & - & & & & & $50 \mathrm{X}$ & & & & & $50 \mathrm{X}$ \\
\hline
\end{tabular}

B

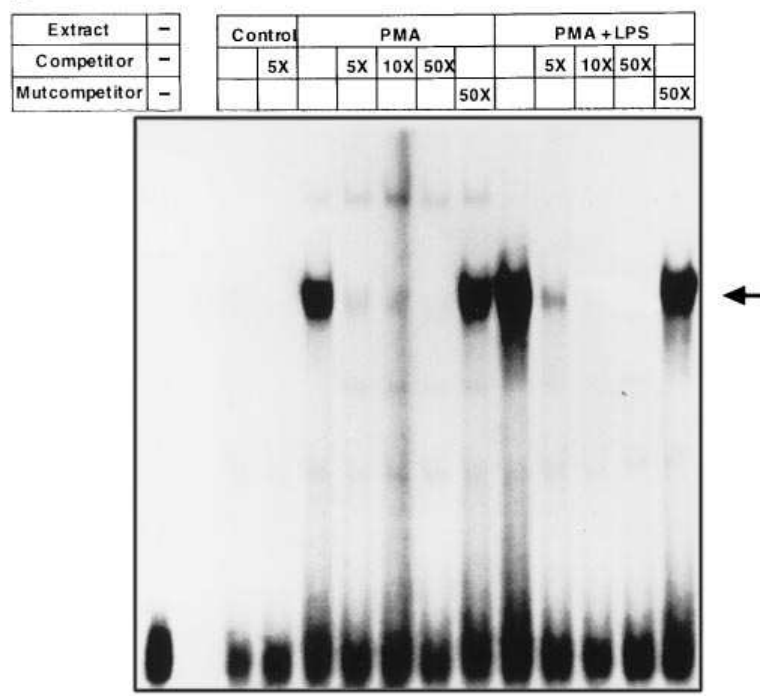

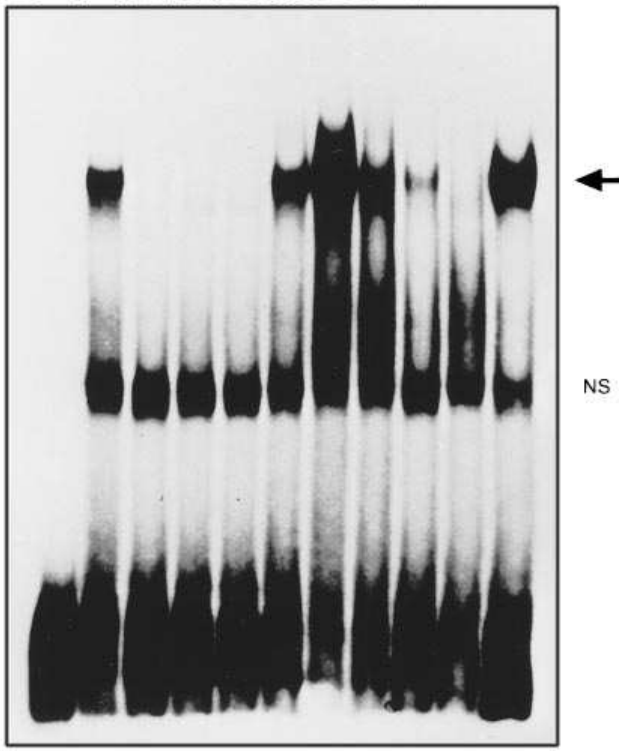

E

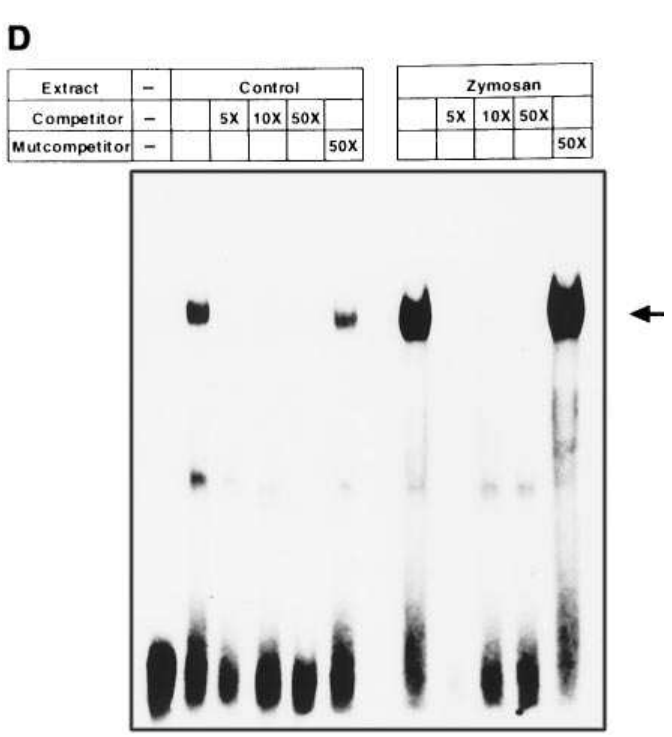

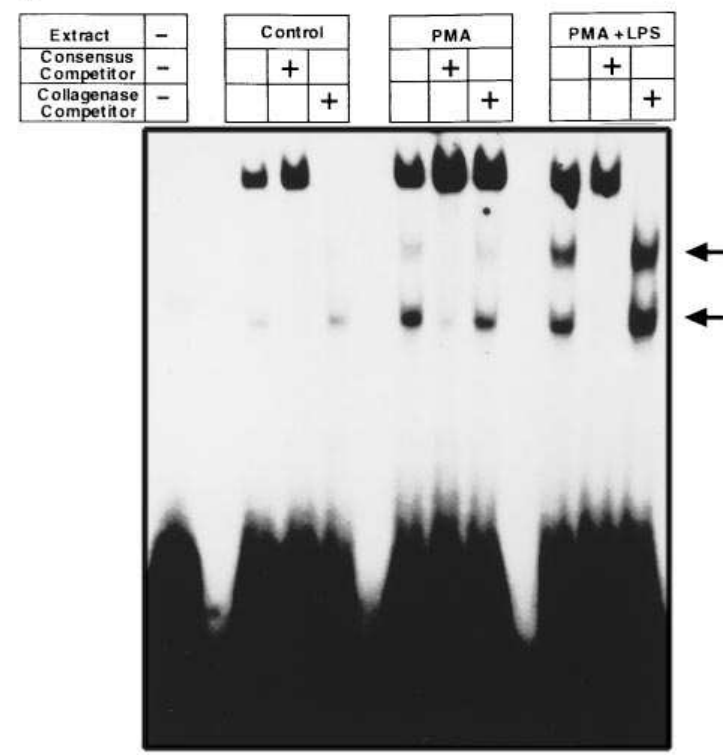

Figure 6. AP-1 and NF- $\kappa \mathrm{B}$ are induced by LPS treatment. $(A)$ Oligonucleotides used in gel-shift assays include the human collagenase MMP-1 AP-1 site, the human collagenase NF-кB-like site, and a consensus NF-кB sequence. $(B)$ Gel-shift assay using the collagenase AP-1 site and $5 \mu \mathrm{g}$ of nuclear extracts derived from U937 cells treated for $24 \mathrm{~h}$ with either control medium, PMA at $50 \mathrm{ng} / \mathrm{ml}$, or MPA at $50 \mathrm{ng} / \mathrm{ml}$ plus LPS at $10 \mu \mathrm{g} / \mathrm{ml}$. Note that specific binding activity is low in the extracts from unstimu-

lated cells, is induced in extracts from PMA-differentiated cells, and is augmented further in nuclear extracts from LPS-treated cells. $(C)$ Gelshift assay using the collagenase AP-1 site and $5 \mu \mathrm{g}$ of nuclear extracts derived from J774 cells treated for $24 \mathrm{~h}$ with control medium or LPS at 10 $\mu \mathrm{g} / \mathrm{ml}$. Note that binding activity is present in the unstimulated cells and is specifically competed by unlabeled excess oligo, but not by mutant competitor. LPS treatment results in markedly increased specific binding activity. $(D)$ Gel-shift assay using $5 \mu \mathrm{g}$ of nuclear extracts prepared from control- or zymosan-treated J774 cells. Zymosan treatment results in increased specific binding to the collagenase AP-1 site. (E) Gel-shift assay using a consensus NF-кB sequence and nuclear extracts from PMA and LPS-treated U937 cells. Binding activity is increased by PMA and LPS-treatment of U937 cells. Note that specific binding (arrows) is competed by excess unlabeled consensus competitor, but not by the collagenase NF-кB-like sequence. 
duction of binding activity to the collagenase AP-1 site was also evident (Fig. $6 \mathrm{D}$ ).

To determine whether the NF- $\mathrm{BB}$-like site in the collagenase promoter is functional in binding $N F-\kappa B$, this sequence was used to compete binding to an NF- $\mathrm{B}$ consensus sequence (Fig. 6 E). Extracts from control U937 cells exhibited some basal level of binding activity for the consensus NF- $\mathrm{KB}$ sequence. This was readily competed by 25 -fold excess unlabeled consensus competitor, but not by a 25 -fold excess of doublestranded oligonucleotide derived from the collagenase promoter. Specific binding to the consensus NF-кB oligonucleotide was increased in extracts from PMA-differentiated cells and markedly induced by LPS treatment. However, similar to the binding activity exhibited in extracts from control cells, this activity was not competed by excess oligonucleotide derived from the collagenase $\mathrm{NF}-\kappa \mathrm{B}-$ like site. These data indicate that while NF-кB activity is induced by LPS treatment, the NF-кBlike site identified in the collagenase promoter does not specifically bind the NF-кB complexes.

C-Jun, Jun B, Jun D, and c-Fos are present in LPS-induced $A P-1$ complexes. To define the specific proteins present in the shifted complexes, antibodies to specific components of AP-1 complexes were used in supershift assays involving LPS stimulation of human U937 cells. Supershifted bands were detected when binding reactions included antibodies to c-Jun, Jun B, and Jun D, indicating these components are present in the AP-1 complexes induced by LPS stimulation of U937 cells (Fig. 7). Similarly, an anti-Fos antibody which recognizes all members of the fos gene family and a specific antibody to c-Fos were used in supershift assays, resulting in altered mobility of the DNA-protein complexes and indicating the presence of c-Fos. In supershift assays employing this same panel of antibodies, but using nuclear extracts from LPS or zymosan-treated J774 cells, the same pattern of results was obtained (data not shown). Thus, the AP-1 complexes induced by LPS in mono-

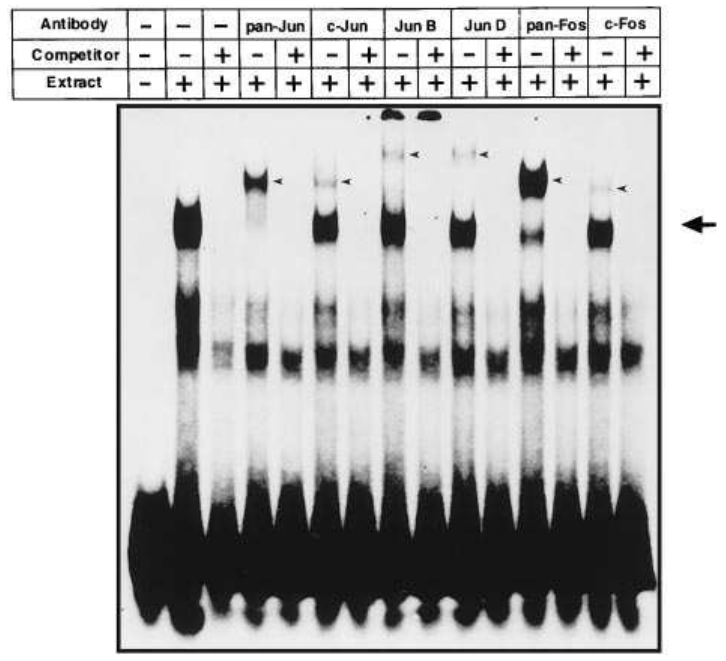

Figure 7. Supershift analysis of nuclear extracts from PMA and LPStreated U937 cells. Gel-shift assay using the collagenase AP-1 site and $5 \mu \mathrm{g}$ of nuclear extracts derived from U937 cells treated for $24 \mathrm{~h}$ with PMA at $50 \mathrm{ng} / \mathrm{ml}$ plus LPS at $10 \mu \mathrm{g} / \mathrm{ml}$. Anti-pan-Jun, c-Jun, Jun B, Jun D, pan-Fos, and c-Fos antibodies added to the incubation resulted in a further decrease in mobility of the PMA and LPS-induced AP-1 complexes (arrow, shifted band; arrowheads, supershifted band). cytic cells contain specific members of both the Jun and Fos families of DNA binding proteins.

\section{Discussion}

In this manuscript, we present the novel finding that a 72-bp sequence of the interstitial collagenase promoter, from the transcription start site to the AP-1 site, is sufficient for maximal fold induction of transcription in monocytic cells. It is widely recognized that AP-1 plays a vital role in transcriptional regulation of matrix metalloproteinases, including interstitial collagenase. There is, however, strong evidence that sequences upstream of the AP-1 site are necessary for maximal fold induction of collagenase transcription in resident cell types.

In 1990, Gutman and Wasylyk (15) reported that in mouse fibroblasts $\left(\mathrm{LMTK}^{-}\right)$, the human collagenase promoter uses a phorbol- and oncogene-responsive unit that encompasses the PEA-3- and AP-1-binding sites. They named this unit TORU (TPA and oncogene-responsive unit). Mutation of the PEA-3 site resulted in markedly lower fold induction of transcription upon phorbol stimulation or cotransfection with oncogene expression vectors. In 1991, two reports from Brinckerhoff and co-workers $(10,14)$ indicated that upstream elements, cooperating with the AP-1 site, were necessary for induction of transcription in fibroblasts. They reported that a PEA-3-like element and also a TTCA sequence were necessary for phorbol inducibility of collagenase transcription in fibroblasts. The minimal promoter fragment which was phorbol responsive was $127 \mathrm{bp}$ in length (14). Similarly, they found that both IL-1 and phorbol induction of the stromelysin promoter requires an upstream element that cooperates with the AP-1 site (10). The fold induction of transcriptional activity in the shortest AP-1containing construct was two- to threefold with IL-1 or phorbol treatment in human skin fibroblasts, but five- to sixfold in constructs containing upstream sequences, indicating that cooperation between the AP-1 site and upstream elements is required for maximal fold induction of stromelysin in fibroblasts. Also in 1991, Buttice et al. (39) reported that the AP-1 site is necessary for basal and maximal activity of the stromelysin promoter, but not for phorbol induction, in human and mouse cells. In 1993, Buttice and Kurkinen (38) demonstrated that the PEA-3 site, $5^{\prime}$ of the AP- 1 site, plays a major role in phorbol induction of the stromelysin gene.

Together, these studies emphasize that in human and mouse fibroblasts, with a variety of stimuli, elements upstream to AP-1 are critical for maximal fold induction of metalloproteinase transcription. Indeed, fold induction was increased by a factor of two to five by inclusion of upstream sequences in these studies.

The previous reports contrast strongly with our findings regarding collagenase induction in monocytic cells. In PMA-differentiated U937 cells, the fold induction of the -72 construct on LPS treatment was similar to the fold induction observed with constructs containing additional $5^{\prime}$ flanking sequences up to $2278 \mathrm{bp}$. Similarly, in murine $\mathbf{J} 774$ cells, the magnitude of LPS induction of a construct containing only $72 \mathrm{bp}$ of $5^{\prime}$ flanking sequence was equal to constructs containing 179,511 , or 2278 bp of 5' flanking sequences (Table I). While absolute promoter activity is maximal with larger constructs in our studies, this finding does not indicate that upstream elements are LPSor zymosan-responsive, but rather that upstream elements are 
necessary for full basal and induced transcriptional activity. This is fundamentally different from the previous studies in resident cells outlined above, where upstream elements were clearly responsive to either phorbol ester or IL-1. In those studies, additional sequences conferred greater fold induction of transcription in response to stimulation.

To our knowledge, this study is the first to delineate collagenase promoter elements responsive to macrophage-specific mediators and to suggest that elements of the collagenase promoter from -72 to the transcription start site alone can be sufficient to mediate this gene's induction in monocytic cells. The cell model systems we used included both PMA-differentiated U937 human monocytic cells and macrophage-like murine J774 cells. Each of these two cell lines offered advantages for this study. Notably, there are no spontaneously adherent human monocytic cell lines capable of responding directly to LPS. Therefore, we used PMA-differentiated human U937 cells, which responded potently to LPS stimulation. We also studied murine J774 cells to complement and validate our studies in the human U937 cells, because these cells are phenotypically very similar to tissue macrophages. They are spontaneously adherent and respond directly to LPS. In murine cells and tissues, however, MMP-13 appears to be the only collagenase present. Indeed, expression of MMP-13 was induced by LPS (Fig. $1 \mathrm{~B}$ ), indicating that these cells possess all the machinery necessary to upregulate metalloproteinase expression, precisely as pulmonary alveolar macrophages do. The identity of results between the phorbol-differentiated U937 cells and J774 cells strongly suggests that the responsive elements of MMP genes and the nuclear factors conferring transactivation operate across mammalian species.

In our studies, induction of nuclear proteins capable of binding the collagenase AP-1 site was markedly upregulated by LPS treatment of PMA-differentiated U937 cells and by LPS or zymosan treatment of J774 cells. Further analysis using antibodies specific for individual components of the AP-1 complexes identified c-Jun, Jun B, Jun D, and c-Fos in protein complexes bound to the AP-1 site. Because the antibodies used may differ in their affinities and efficiency of binding under experimental conditions, these assays do not ascertain which of these components are predominant. Angel and Karin (1992) showed that c-Jun is necessary for collagenase activation (40). If this requirement for c-Jun is operative in transactivation of monocytic cells as well, c-Jun/c-Fos heterodimers may predominate in LPS- or zymosan-stimulated macrophagelike cells.

LPS binding to CD14 on the cell surface (41) starts a cascade of signal transduction which ultimately results in the activation of the AP-1 and $\mathrm{NF}-\kappa \mathrm{B}$ transcription factors, among others (28). We identified an NF-кB-like sequence in the collagenase promoter between the TATA box and transcription initiation site, yet mutation of this site failed to affect LPSmediated transactivation. The binding of nuclear proteins from LPS-stimulated cells to a consensus NF-кB site derived from the immunoglobulin kappa gene enhancer indicated that NF- $\kappa \mathrm{B}$ was strongly upregulated by LPS treatment; however, this binding activity was not efficiently competed by excess unlabeled collagenase NF-кB-like sequences. In contrast, deletion or mutagenesis of the AP-1 site completely abrogated collagenase transactivation in response to LPS treatment. Therefore, collagenase transactivation by LPS in dependent upon AP-1, but exhibits no involvement of this NF-kB-like site. While we cannot rule out participation of other sequences of the collagenase gene (in addition to -2278 to +36 ) in the LPS-mediated transcriptional induction in macrophages, it is clear that the sequences between -72 and -55 , including the AP-1 site, are critical for this response.

In this report, we have shown that upstream promoter elements such as PEA-3 and TTCA, which are required for resident cell induction of collagenase expression, contribute little or nothing to transcriptional activation of the collagenase gene in monocytic cells. Indeed, our data suggest that elements of the collagenase promoter from -72 to the transcription start site alone can be sufficient to mediate this gene's induction in response to macrophage-specific mediators such as LPS and zymosan. These results emphasize the cell type-specific differences which exist in metalloproteinase expression and may have important implications for understanding pathogenetic mechanisms in diseases such as atherosclerosis and rheumatoid arthritis.

\section{Acknowledgments}

We thank Dr. William Parks for helpful discussions and Dr. Stephen Frisch for providing pCLCAT.

This work was supported by grants HL-29594 and HL-54049 from the National Institutes of Health and a Career Development Award from the Dermatology Foundation.

\section{References}

1. Welgus, H.G., J.J. Jeffrey, and A.Z. Eisen. 1981. The collagen substrate specificity of human skin fibroblast collagenase. J. Biol. Chem. 256:9511-9515.

2. Goldberg, G.I., S.M. Wilhelm, A. Kronberger, E.A. Bauer, G.A. Grant, and A.Z. Eisen. 1986. Human fibroblast collagenase. Complete primary structure and homology to an oncogene transformation-induced rat protein. J. Biol. Chem. 261:6600-6605.

3. Hasty, K.A., T.F. Pourmotabbed, G.I. Goldberg, J.P. Thompson , D.G. Spinella, R.M. Steens, and C.L. Mainardi. 1990. Human neutrophil collagenase. A distinct gene product with homology to other matrix metalloproteinases. $J$. Biol. Chem. 265:11421-11424.

4. Quinn, C.O., D.K. Scott, C.E. Brinckerhoff, L.M. Matrisian, J.J. Jeffrey, and N.C. Partridge. 1990. Rat collagenase: cloning, amino acid sequence comparison, and parathyroid hormone regulation in osteoblastic cells. J. Biol. Chem. 265:22342-22347.

5. Freije, J.M.P., I. Diez-Itza, M. Balbin, L.M. Sanchez, R. Blasco, J. Tolivia, and C. Lopez-Otin. 1994. Molecular cloning and expression of collagenase-3, a novel human matrix metalloproteinase produced by breast carcinomas. J. Biol. Chem. 269:16766-16773.

6. Murphy, G., M.I. Crockett, R.V. Ward, and A.J.P. Docherty. 1991. Matrix metalloproteinase degradation of elastin, type IV collagen and proteoglycan. A quantitative comparison of the activities of $95 \mathrm{kDa}$ and $75 \mathrm{kDa}$ gelatinases, stromelysins- 1 and -2 and punctuated metalloproteinase (PUMP). Biochem. J. 277:277-279.

7. McDonnell, S.E., L.D. Kerr, and L.M. Matrisian. 1990. Epidermal growth factor stimulation of stromelysin mRNA in rat fibroblasts requires induction of protooncogenes $c$-fos and $c$-jun and activation of protein kinase C. Mol. Cell. Biol. 10:4284-4293.

8. Edwards, D.R., G. Murphy, J.J. Reynolds, S.E. Whitham, A.J.P. Docherty, P. Angel, and J.K. Heath. 1987. Transforming growth factor modulates the expression of collagenase and metalloproteinase inhibitor. EMBO (Eur. Mol. Biol. Organ.) J. 6:1899-1904.

9. Brenner, D.A., M. O’Hara, P. Angel, M. Chojkier, and M. Karin. 1989. Prolonged activation of jun and collagenase genes by tumor necrosis factor- $\alpha$. Nature (Lond.). 337:661-663.

10. Sirum-Conolly, K., and C.E. Brinckerhoff. 1991. Interleukin-1 or phorbol induction of the stromelysin promoter requires an element that cooperates with AP-1. Nucleic Acids Res. 19:335-341.

11. Cury, J.D., E.J. Campbell, C.J. Lazarus, R.J. Albin, and H.G. Welgus. 1988. Selective upregulation of human alveolar macrophage collagenase production by lipopolysaccharide and comparison to collagenase production in fibroblasts. J. Immunol. 14:4306-4312.

12. Shapiro, S.D., D.K. Kobayashi, and H.G. Welgus. 1992. Identification of TIMP-2 in human alveolar macrophages. Regulation of biosynthesis is opposite to that of metalloproteinases and TIMP-1. J. Biol. Chem. 267:13890-13894. 
13. Saarialho-Kere, U.K., H.G. Welgus, and W.C. Parks. 1993. Divergent mechanisms regulate interstitial collagenase and $92 \mathrm{dKa}$ gelatinase expression in human monocytic-like cells exposed to bacterial endotoxin. J. Biol. Chem. 268:17354-17361.

14. Auble, D.T., and C.E. Brinkerhoff. 1991. The AP-1 sequence is necessary but not sufficient for phorbol induction of collagenase in fibroblasts. Biochemistry. 30:4629-4635.

15. Gutman, A., and B. Wasylyk. 1990. The collagenase gene promoter contains a TPA and oncogene-responsive unit encompassing the PEA3 and AP-1 binding sites. EMBO (Eur. Mol. Biol. Organ.) J. 9:2241-2246.

16. Firestein, G.S., M.M. Paine, and B.H. Littman. 1991. Gene expression (collagenase, tissue inhibitor of metalloproteinases, complement, and HLADR) in rheumatoid arthritis and osteoarthritis synovium. Quantitative analysis and effect of intraarticular corticosteroids. Arthritis \& Rheum. 34:1094-1105.

17. McCachren, S.S. 1991. Expression of metalloproteinases and metalloproteinase inhibitor in human arthritic synovium. Arthritis \& Rheum. 34:10851093.

18. Galis, Z.S., M.W. Suckhova, M.W. Lark, and P. Libby. 1994. Increased expression of matrix metalloproteinases and matrix degrading activity in vulnerable regions of human atherosclerotic plaques. J. Clin. Invest. 94:2493-2503.

19. Nikkari, S.T., K.D. O’Brien, M. Ferguson, T. Hatsukami, H.G. Welgus, C.E. Alpers, and A.W. Clowes. 1995. Interstitial collagenase (MMP-1) expression in human carotid atherosclerosis. Circulation. 92:1393-1398.

20. Hazuda, D.J., J.C. Lee, and P.R. Young. 1988. The kinetics of IL-1 secretion from activated monocytes. Differences between interleukin $1 \alpha$ and interleukin 1ß.J. Biol. Chem. 263:8473.

21. Beutler, B., N. Krochin, I.W. Milsark, C. Leudke, and A. Cerami. 1986. Control of cachectin (tumor necrosis factor) synthesis: mechanisms of endotoxin resistance. Science (Wash. DC). 249:977.

22. Bauer, J., U. Ganter, T. Geiger, U. Jacobshagen, T. Hirano, T. Matsuda, T. Kishimoto, T. Andus, G. Acs, W. Gerok, et al. 1988. Regulation of interleukin-6 expression in cultured human blood monocytes and monocyte-derived macrophages. Blood. 72:1134.

23. Collart, M.A., P. Bauerle, and P. Vassali. 1990. Regulation of tumor necrosis factor alpha transcription in macrophages: involvement of four $\mathrm{\kappa B}-$ like motifs and of constitutive and inducible forms of NF-кB. Mol. Cell. Biol. 10: 1498-1506.

24. Goldfield, A.E., C. Doyle, and T. Maniatis. 1990. Human tumor necrosis factor $\alpha$ gene regulation by virus and lipopolysaccharide. Proc. Natl. Acad. Sci. USA. 87:9769-9773.

25. Drouet, C., A.N. Shakhov, and C.V. Jongeneel. 1991. Enhancers and transcription factors controlling the inducibility of the tumor necrosis factor- $\alpha$ promoter in primary macrophages. J. Immunol. 147:1694-1700.

26. Ways, J.P., and J.G. Gray. 1994. NF-kappa B regulates IL-1 beta transcription through a consensus NF-kappa B binding site and a nonconsensus CRE-like site. J. Immunol. 153:712-723.
27. Mackman, N., K. Brand, and T.S. Edgington. 1991. Lipopolysaccharidemediated transcriptional activation of the human tissue factor gene in THP-1 monocytic cells requires both activator protein 1 and nuclear factor $\mathrm{kB}$ binding sites. J. Exp. Med. 174:1517-1526.

28. Lenardo, M.J., and D. Baltimore. 1989. NF-kB: a pleiotropic mediator of inducible and tissue-specific gene control. Cell. 58:227-229.

29. Pierce, R.A., W.I. Mariencheck, S. Sandefur, E.C. Crouch, and W.C. Parks. 1995. Glucocorticoids upregulate tropoelastin expression during late stages of fetal lung development. Am. J. Physiol. 268:L491-L500.

30. An, G., K. Hidaka, and L. Siminovitch. 1982. Expression of bacterial $\beta$ galactosidase in animal cells. Mol. Cell. Biol. 2:1628-1632.

31. Gorman, C.M., L.F. Moffat, and B.H. Howell. 1982. Recombinant genes which express chloramphenicol acetyltransferase in mammalian cells. Mol. Cell. Biol. 2:1044-1051.

32. Chomczynski, P., and N. Sacchi. 1987. Single-step method of RNA isolation by acid guanidinium thiocyanate-phenol-chloroform extraction. Anal. Biochem. 162:156-159.

33. Fort, P., M. Piechaczyk, S. El Sabrouty, C. Danz, I. Jeatner, and J.M. Blanchard. 1985. Various rat adult tissues express only one major mRNA species from the glyceraldehyde-3-phosphate multigene family. Nucleic Acids Res. 13:1431-1442.

34. Luckow, B., and G. Schutz. 1987. CAT constructions with multiple unique restriction sites for the functional analysis of eukaryotic promoters and regulatory elements. Nucleic Acids Res. 15:5490.

35. Ho, S.N., H.D. Hunt, R.M. Horton, J.K. Pullen, and L.R. Pease. 1989. Site-directed mutagenesis by overlap extension using the polymerase chain reaction. Gene (Amst.). 77:51-59.

36. Dignam, J., P. Martin, B. Shastry, and R. Roeder. 1983. Eucaryotic gene transcription with purified components. Methods Enzymol. 101:582-598.

37. Ausubel, F.M., R. Brent, R.E. Kingston, D.D. Moore, J.G. Seidman, J.A. Smith, and K. Struhl. 1987. Current Protocols in Molecular Biology. John Wiley and Sons, Inc., New York. 12.1.1-12.1.10.

38. Buttice, G., and M. Kurkinen. 1993. A Polyoma Enhancer A-binding Protein-3 site and Ets protein have a major role in the 12-O-tetradecanoylphorbol-13-acetate response of the human stromelysin gene. J. Biol. Chem. 268: 7196-7204.

39. Buttice, G., S. Quinines, and M. Kurkinien. 1991. The AP-1 site is required for basal expression but is not necessary for TPA-response of the human stromelysis gene. Nucleic Acids Res. 19:3723-3731.

40. Angel, P., and M.I. Karin. 1992. Specific members of the jun protein family regulate collagenase expression in response to various extracellular stimuli. In Matrix Metalloproteinases and Inhibitors. H. Birkedahl-Hansen, Z. Werb,

H.G. Welgus, and H.E. van Wart, editors. Gustav Fischer, Stuttgart. 156-164.

41. Wright, S.D., R.A. Ramos, P.S. Tobias, R.J. Ulevitch, and J.C. Mathison. 1990. CD14, a receptor for complexes of lipopolysaccharide (LPS) and LPS binding protein. Science (Wash. DC). 249:1431-1433. 